\begin{tabular}{|c|c|}
\hline $\int_{\text {Marburg }}$ & $\begin{array}{l}\text { Joint Discussion Paper } \\
\text { Series in Economics } \\
\text { by the Universities of } \\
\text { Aachen · Gießen · Göttingen } \\
\text { Kassel · Marburg · Siegen } \\
\text { ISSN 1867-3678 }\end{array}$ \\
\hline
\end{tabular}

No. 23-2009

Bernd Hayo, Ali M. Kutan, and Matthias Neuenkirch

\title{
Federal Reserve Communications and Emerging Equity Markets
}

This paper can be downloaded from

http://www.uni-marburg.de/fb02/makro/forschung/magkspapers/index_html\%28magks\%29

Coordination: Bernd Hayo • Philipps-University Marburg

Faculty of Business Administration and Economics - Universitätsstraße 24, D-35032 Marburg Tel: +49-6421-2823091, Fax: +49-6421-2823088, e-mail: hayo@wiwi.uni-marburg.de 


\title{
Federal Reserve Communications and Emerging Equity Markets
}

\author{
Bernd Hayo*, Ali M. Kutan ${ }^{+}$, and Matthias Neuenkirch* \\ *Philipps-University Marburg \\ ${ }^{+}$Southern Illinois University, Edwardsville; Emerging Markets Group, London; \\ William Davidson Institute, Michigan
}

This version: 2 December 2010

Corresponding author:

Bernd Hayo

Faculty of Business Administration and Economics

Philipps-University Marburg

D-35032 Marburg

Germany

Tel.: +49-6421-2823091

Fax: +49-6421-2823088

Email: hayo@wiwi.uni-marburg.de

\footnotetext{
* Thanks to two anonymous referees, Paolo Gelain, Jan-Egbert Sturm, and participants of the MAREM macroeconomics workshop in Tübingen and the 13th International Conference of Macroeconomic Analysis and International Finance in Rethymno for their helpful comments on earlier versions of the paper. Of course, all remaining errors are our own.
} 


\title{
Federal Reserve Communications and Emerging Equity Markets
}

\begin{abstract}
Work on the impact of U.S. monetary policy on emerging financial markets mostly focuses on official federal funds rate announcements; empirical evidence using data on informal communication channels, such as speeches, is scant. Employing a unique data set covering formal and informal communication channels in a GARCH model framework, we provide comprehensive evidence on the effects of U.S. monetary policy on 17 emerging equity market returns over the period 1998-2009. We find, first, that both monetary policy actions and communications have a significant impact on market returns. Second, target rate change surprises are an important driver of emerging market returns. However, informal communications-particularly when taking into account their higher frequency-have a larger (cumulative) influence on returns than do target rate surprises. Third, during the financial crisis, central bank communication plays an even more pronounced role. Finally, American emerging markets react more to U.S. central bank communications than do nonAmerican markets. We discuss the policy implications of the findings.
\end{abstract}

JEL: $\quad$ E52, G14, G15

Keywords: Central Bank Communication, Emerging Markets, Federal Reserve, Financial Crisis, Monetary Policy 


\section{Introduction}

According to the Coordinated Portfolio Investment Survey, published by the International Monetary Fund, the United States is the world's largest investor. U.S. investors held about $30 \%$ of the world's reported portfolio investment assets throughout 2001-2009. The U.S. dollar dominates the payment flows of private international transactions; it was involved in 89\% of all currency transactions in 2009. Given this importance of the United States to international capital flows, it is likely that news about U.S. monetary policy influences stock markets around the world. During the recent financial crisis, we expect central bank actions and communications to play an even more pronounced role. Like many other central banks, the U.S. Federal Reserve (Fed) implemented various measures, in addition to lowering shortterm interest rates, to mitigate the effects of the crisis. As some of these additional measures are "unorthodox," the Fed also put a lot of emphasis on communication in an effort to explain and prepare the public for them.

Given the importance of the Fed during normal times, as well as in times of crisis, it is unsurprising that the impact of U.S. monetary policy on foreign equity indexes is investigated frequently. However, the focus of this work is chiefly on formal policy announcements. The starting point of our analysis is the expectation that financial markets not only adjust to formal monetary policy announcements, but also to informal channels of communication by the Fed, such as speeches and testimony by Board of Governors members. Consequently, one would expect agents in foreign equity markets to take into account informal U.S. monetary policy news in addition to formal news. For instance, Hayo et al. (2010) show that mature European and Pacific equity market returns react significantly to different types of informal communication by Fed officials. An important unexplored research question is whether emerging financial markets have a similar reaction to informal U.S. monetary policy communication.

In this paper, we address four research questions. First, does U.S. monetary policy action and communication have an economically significant impact on equity returns in emerging markets? Second, if so, do markets react differently to official rate changes versus less formalized channels of monetary policy like speeches and testimony? Third, is there a different reaction to U.S. monetary policy measures during the financial crisis, which began in August 2007? Finally, are there region-specific differences in emerging market reactions? Answers to these questions have significant policy implications. For example, if informal communications move the markets as much as official announcements, officials need to be cautious about what they say-especially during a crisis period-and investors need to 
account for the effects of informal channels in their hedging and portfolio selection. If the findings indicate a significant transmission of communication of U.S. monetary policy to emerging economies via financial markets and this is not desirable, policymakers in these economies need to design effective policies to shield their markets from such influences.

The remainder of this paper is organized as follows. In Section 2, we provide a brief overview of the extant literature and how it relates to our contribution. Section 3 describes the construction of monetary policy news and presents the econometric methodology. In Section 4, we illustrate our results. Section 5 concludes with the policy implications of our findings.

\section{Related Literature and Our Contribution}

A growing literature investigates the effects of U.S. news-particularly U.S. monetary policy actions_-on emerging markets. Hausman and Wongswan (2006) document the impact of U.S. monetary policy announcement surprises on financial markets in 49 countries. Global equity indexes respond chiefly to the target surprise; exchange rates and long-term interest rates respond mainly to the path surprise (a revision to the path of future monetary policy); and short-term interest rates respond to both surprises. Equity indexes and interest rates in countries with a less flexible exchange rate regime respond more to U.S. monetary policy surprises. In addition, the percentage of each country's equity market capitalization owned by U.S. investors and the share of each country's trade that is with the United States are also important factors in explaining the variation.

Ehrmann and Fratzscher (2009) analyze 50 equity markets worldwide and show that returns fall on average around $2.7 \%$ in response to a 100 basis point tightening of U.S. monetary policy. A stronger effect of the policy is found for countries that have open and relatively more liquid financial markets. They also find that the degree of global real and financial integration, not a country's bilateral integration with the United States, is a key determinant of the policy transmission process. Wongswan (2009) documents the impact of U.S. monetary policy surprises on equity indexes in 15 developed and emerging countries. He illustrates that an unanticipated 25 basis point cut in the federal funds target rate is associated with a $0.5-2.5 \%$ increase in foreign equity indexes. The variation in response across countries is more related to the degree of financial integration these countries have with the United States, rather than with trade linkages or the degree of exchange rate flexibility. Robitaille and Roush (2006) find that an increase in U.S. interest rates due to Federal Open Market Committee (FOMC) decisions results in a systematic increase in bond spreads and a decline 
in stock prices in Brazil. Their results suggest that financial linkages play a greater role than real economic linkages in determining the response of Brazilian asset values to U.S. news.

Several papers focus on how emerging bond markets react to U.S. target rate changes and other nonmonetary policy news. Andritzky et al. (2007) show that global bond spreads respond to rating actions and changes in U.S. interest rates rather than to domestic data and policy announcements. Examining country subsamples, they discover that U.S. news matters less to countries with more transparent policies and higher credit ratings. Arora and Cerisola (2001) show that stance and predictability of U.S. monetary policy are important for stabilizing capital flows and capital market conditions in emerging markets. Alper (2006) concludes that the unanticipated component of U.S. monetary policy is significant in explaining movements in emerging markets’ sovereign bond spreads. Özatay et al. (2009) demonstrate that EMBI spreads in 18 emerging markets respond substantially to U.S. macroeconomic news and changes in the Federal Reserve's target rate. The magnitude and sign of the effect of U.S. news, however, crucially depend on the state of the U.S. economy. Uribe and Yue (2006) illustrate that in response to an increase in U.S. interest rates, emerging country spreads first fall and then display a delayed but large overshooting pattern.

Miniane and Rogers (2007) find that capital controls do not effectively insulate countries from U.S. monetary policy shocks. Countries with more stringent capital controls do not experience smaller interest rate increases in response to contractionary U.S. monetary shocks than do countries without capital controls. Other factors, such as exchange rate regime or degree of dollarization, explain more of the cross-country differences. Dailami et al. (2008) discover that U.S. interest rates affect secondary market spreads differently, depending on countries’ debt levels. Moderate sovereign debtors suffer little impact from an increase in U.S. interest rates, whereas countries close to insolvency face a much steeper increase in their spread. Fender et al. (2010) show that U.S. monetary policy actions and communications have at least as much of an economic influence on emerging market credit default spreads as do changes in country ratings.

Empirical evidence using data on informal communication channels in the context of emerging markets is scant. The literature (for a comprehensive survey, see Blinder et al., 2008) focuses mostly on mature markets and shows how important a tool communication is for central bankers. Communication helps market participants make necessary adjustments gradually in the run-up to the expected interest rate decision. There are several interesting 
patterns that emerge from the related literature. ${ }^{1}$ First, central bank communications regarding the economic outlook (EO) and the course of monetary policy (MP) have a significant impact on domestic financial market returns and volatility. Second, the impact on financial markets is larger when the communication channel is more formal: post-meeting statements accompanying interest decisions or monetary policy reports are more important than speeches and congressional hearings. Third, if the speaker has a more prominent position on the respective committee, financial markets react more significantly.

In this paper, we extend existing work by examining the effects of U.S. monetary policy actions and communications (post-meeting statements, monetary policy reports, testimony, and speeches) on emerging equity market returns. We employ a GARCH model with country-specific fixed effects to capture the autoregressive conditional heteroscedasticity that characterizes many financial series. The GARCH approach allows estimating these series more efficiently, taking into account time-varying conditional volatility of asset prices. Our contribution to the literature lies in the use of a new data set that captures less formalized channels of U.S. monetary policy, in addition to formal channels, and an empirical investigation into their relative impact on emerging equity markets. Finally, to the best of our knowledge, this is the first study on informal communication that also covers the recent financial crisis and we explicitly address the question of whether there is a different financial market reaction in "crisis times" compared to "normal times."

Our analysis focuses on emerging stock markets because they tend to be exposed to foreign news and, in particular, U.S. news for several reasons. Emerging economies rely on foreign investments to finance their catching-up process. They are also highly integrated with the U.S. economy via international trade. For example, an upswing in the U.S. economy is bound to improve the domestic economic outlook and hence increase trade flows between emerging economies and the United States. Emerging market economies are typically small and open, and tend to import inflation via exchange rate pass-through. Finally, emerging markets are characterized by the increasing global financial market integration itself. Thus, we would expect that emerging financial markets react to U.S. monetary policy news.

\footnotetext{
${ }^{1}$ For instance, see, among many others, Guthrie and Wright (2000) for the Reserve Bank of New Zealand; Andersson et al. (2006) for the Sveriges Riksbank; Connolly and Kohler (2004) for six central banks; Ehrmann and Fratzscher (2007) for three central banks; Hayo et al. (2008) for the Fed; Hayo and Neuenkirch (2010) for the Bank of Canada; Ranaldo and Rossi (2010) for the Swiss National Bank.
} 


\section{Data and Econometric Methodology}

In our analysis, we use a new data set introduced by and described in detail in Hayo et al. (2008) and extend it until December 2009 to include more observations for the recent crisis period. The data set covers 837 speeches and 201 congressional hearings by Board of Governors members, as well as 94 post-meeting statements and 26 monetary policy reports (MPR). ${ }^{2}$ Following the literature (e.g., Ehrmann and Fratzscher, 2007), we sort the communication content into two categories: monetary policy or economic outlook. Coding for U.S. economic outlook is either "positive” $(\mathrm{EO}+)$ or "negative” (EO-). “Tightening” (MP+) or "easing” (MP-) are the categories for the Fed's monetary policy stance. We employ dummy variables that are split into positive and negative news to take into account possible asymmetrical reactions of financial markets. ${ }^{3}$ In total, there are 16 communication dummies as the four types (statements, MPR, testimony, speeches) can be coded into the four different categories $\mathrm{EO}+, \mathrm{EO}-, \mathrm{MP}+$, and $\mathrm{MP}-$.

In designing these news categories, we carefully read the speeches twice and then coded them independently into the appropriate dummy categories. In the case of an intercoder conflict, we read the speech yet again and adjusted our indicators accordingly. We employed extensive robustness checks to ensure that our results do not depend on the particular coding of ambiguous individual observations. We provide a few examples of speeches, along with our classification scheme, in the Appendix.

We also incorporate several variables controlling for the additional measures undertaken by the Fed during the financial crisis. These are grouped into five categories: (i) the discount rate change on August 17, 2007, (ii) the announcement of joint initiatives with the federal government, (iii) the announcement of additional unilateral liquidity actions, (iv) the announcement of internationally coordinated liquidity actions, and (v) the announcement of measures to mitigate the problems in the asset-backed security market.

Our emerging market indicator comprises daily closing returns on stock markets ${ }^{4}$ in 17 countries over the period January 2, 1998 to December 31, 2009. ${ }^{5}$ The sample consists of

\footnotetext{
${ }^{2}$ Hayo et al. (2008) also provide data for speeches by regional Fed presidents. Their results show that presidents' speeches do not have any systematic influence on U.S. financial market returns. Therefore, we omit these communications from our analysis.

${ }^{3}$ For example, evidence of this type of asymmetry can be found in the impact of IMF statements on financial returns in emerging markets (Hayo and Kutan, 2005) or in the effects of FOMC communication on U.S. financial market returns (Hayo et al., 2008).

${ }^{4}$ We attempted to extend our analysis to bond and foreign exchange markets. To avoid problems with de jure or de facto pegged exchange rate regimes, we selected only those countries classified by Reinhart and Rogoff (2004) as having flexible exchange rate regimes. However, country-specific estimations, as well as pooled regressions, led to puzzling results, in which no systematic pattern could be discerned. Possibly, these markets are either not liquid enough or they react more strongly to domestic news. Given these preliminary findings, we decided to concentrate the analysis on stock markets.
} 
50,881 observations (17 countries and 2,993 days). The country selection is based on the June 2006 Emerging Market Index by Morgan Stanley and includes Argentina, Brazil, Chile, China, Egypt, India, Indonesia, Israel, Jordan, Malaysia, Mexico, Pakistan, Peru, the Philippines, Russia, South Africa, and Thailand. ${ }^{6}$ Composite stock returns for the stacked sample with country-specific fixed effects are computed by taking the first differences of logged daily stock price indices. The use of a panel framework is helpful for obtaining a larger number of observations for each type of news and it improves estimation efficiency. Potential problems associated with panel data estimation involve assuming equal coefficients across countries and a common error structure.

Descriptive statistics show that the emerging market series exhibit excess kurtosis but almost no skewness (see Table A1 in the Appendix), indicating volatility clustering (Engle, 1982). Since preliminary OLS estimations show significant ARCH effects $(F(1,50879)=$ 870.2**), we employ a GARCH model. We start with a general GARCH(1,1) specification (Bollerslev, 1986) as follows:

(1) Returns $_{t}=\gamma+\sum_{r=1}^{6} \delta_{r}$ Control Variables Var $_{r}+\zeta$ Country Dummies

$+\eta$ Day of the Week $+\theta$ Target Rate Changes $_{t}+v$ Communication Dummies $_{t}$

$+\lambda 9 / 11+\xi h_{t}+\mu_{t}$

$\mu_{t}=\epsilon_{t} h_{t}^{1 / 2}$,

$h_{t}=\alpha_{0}+\alpha_{1}\left(\mu_{t-1}-\kappa_{1}\right)^{2}+\kappa_{2} \tau\left(\mu_{t-1}-\kappa_{1}\right)^{2}+\beta_{1} h_{t-1}$,

$\tau=1$ if $\mu_{t-1}<\kappa_{1}$ and zero otherwise,

where $\alpha_{0}, \alpha_{1}, \beta_{1}, \mu, \kappa_{1}, \kappa_{2}, \gamma, \delta, \zeta, \eta, \theta, v, \lambda$, and $\xi$ are parameters or vectors of parameters, $\tau$ is an indicator function as defined in the last line above, $\varepsilon_{\mathrm{t}} \mid \Gamma_{\mathrm{t}-1}=\mathrm{t}(\mathrm{v})$, with $\Gamma_{\mathrm{t}-1}$ capturing all the information up to $t-1$, and $t(v)$ is a t-distribution with $v$ degrees of freedom.

\footnotetext{
${ }^{5}$ We choose daily data instead of intra-day data for two reasons. At a conceptual level, we are interested in the question of whether there are effects of economic importance characterized by a minimum degree of persistence over time instead of just picking out short blips in the data. At a practical level, we find it impossible to time the central bank communications precisely in, say, 10-minute intervals, as is possible in the case of newswire reports.

${ }^{6}$ We omitted six countries from the Morgan Stanley Index as they can no longer be categorized as "true" emerging markets: the Czech Republic, Hungary, and Poland are members of the European Union and the OECD. Büttner et al. (2009) find that European news rather than U.S. news has an impact on these markets. Korea and Turkey are members of the OECD; Taiwan is omitted due to its large market capitalization. To confirm that our selection of countries is appropriate, we calculate country-specific models and find that these countries are not affected as systematically as our selection of "emerging" markets and have different reactions to news. Colombia and Morocco are left out as data for these countries are not available for the full period 19982009.
} 
The general specification (Equation (1)) is an autoregressive-distributed lag model with six lags. The vector of control variables contains past emerging market returns, S\&P 1200 returns to proxy world stock market conditions, growth rates of the corresponding EMBIG regional spreads ${ }^{7}$ to approximate an emerging market bond environment, and growth rates of the broad U.S. dollar index to control for movements in the external value of the U.S. dollar. ${ }^{8}$ The contemporaneous other market returns and U.S. returns are omitted to avoid simultaneity problems. Country-specific effects ${ }^{9}$ and day of the week effects ${ }^{10}$ are captured by dummies. Equation (1) has several special features. First, student-t distributed errors (Bollerslev, 1987) are assumed; these provide a better approximation to residuals that are not normally distributed. Second, the variance enters the mean equation (Engle et al., 1987) to test whether volatility as a measure of risk is priced in the markets. Asymmetric effects of shocks (Engle and Ng, 1993), defined as the last period's forecast errors, are included in the model if $\kappa_{1}$ is significantly different from zero. In addition, asymmetry thresholds (Glosten et al., 1993) are captured when $\kappa_{2}$ is not equal to zero.

Target rate changes (split into expected hikes, expected cuts, surprise hikes, and surprise cuts), ${ }^{11}$ Federal Reserve communications, and the additional measures taken during the financial crisis are included on the day the news actually reaches the respective market, which means we need to account for time-zone differences, as, e.g., a noon speech in the United States is heard in the Philippines after that country's stock exchange has closed. The timing issue is illustrated in Figure 1. According to this stylized schedule, the variables enter the equation on the day the news actually hits the respective market. To disentangle the influence of Fed actions and communications during the financial crisis from the ones during "normal times," we create additional interaction variables for the former during the financial crisis. $^{12}$

\footnotetext{
${ }^{7}$ An augmented Dickey-Fuller (1979) test shows that all regional EMBIG series are non-stationary in log levels but stationary in growth rates.

${ }^{8}$ Data sources: Thomson Datastream for stock market data, JPMorgan for EMBIG Spread, and Federal Reserve statistical release H.10 for Broad U.S. FX index.

${ }^{9}$ Argentina is used as base category for the country dummies.

${ }^{10}$ Monday is used as reference day.

${ }^{11}$ Bloomberg surveys are used to identify surprises from scheduled meetings. Inter-meeting moves are naturally classified as surprises. Target rate changes are coded as follows: 25 bps change: 1; 50 bps change: 2; 75 bps change: 3; otherwise: 0 .

${ }^{12}$ We decided against separate estimations for pre-crisis and crisis periods and in favor of a nested model, for three reasons. First, we can now directly test for differences across coefficients. Second, the number of observations for each subsample varies considerably (2,392 during normal times; 601 during the crisis). Third, the communication variables also vary noticeably. In pre-crisis times, we have a tightening and easing cycle and the accompanying communications. In contrast, during the crisis we have only one easing cycle and indications of easing.
} 
Figure 1: Example of news timing in a different time zone

Foreign trading day t-1
Foreign trading day $\mathrm{t}-1$ after market closure/ day t before market opening

Speech is delivered during U.S. trading hours/news hits U.S. market
Foreign trading day $\mathrm{t}$

News actually hits foreign market timed at day $\mathrm{t}$

Next, we explore the heterogeneity in our sample in more detail by conducting separate regressions for each country, ${ }^{13}$ and discover that there are notable differences in the reaction of the American countries-Argentina, Brazil, Chile, Mexico, and Peru—compared to countries in the rest of the world. The former react to various forms of communication, while the latter are affected by only a few variables. Figure 1 reveals an obvious difference in the transmission mechanism: in American countries, speeches and target rate changes mostly occur during trading hours; in other countries, these events take place after market closure (or before market opening on the subsequent day). Although we address this timing problem by coding the news on the day it actually hits the respective markets, the difference between American markets and the rest of the world remains. To deal with this heterogeneity in the panel, we create separate target rate and communication variables for the American and the non-American countries. Accordingly, asymmetric adjustments across American and nonAmerican equity markets are also captured by separate coefficients for each region on the lagged dependent variable and financial market control variables.

The general GARCH(1,1) model consists of 157 variables and seven GARCH terms. Starting from this comprehensive model, we exclude all the insignificant variables in a general-to-specific testing-down approach (see Hendry, 2000). The final model contains 47 variables and seven GARCH terms (restriction test: $\operatorname{Chi}^{2}(110)=125.4$ ) and removes the volatility clustering in the residuals. The estimates show that we can rule out an integrated GARCH process (Nelson, 1990; Chi $^{2}(1)=28.3^{* *}$ ).

\section{Impact on Emerging Equity Market Returns}

In this section, we describe the impact of U.S. central bank communication and target rate changes on emerging equity market returns.

\footnotetext{
${ }^{13}$ To conserve space, these regressions are not reported in detail. All omitted results are available upon request.
} 
Table 1: Explaining Emerging Market Equity Returns

\begin{tabular}{|c|c|c|}
\hline & America & Non-America \\
\hline$\alpha_{0}$ & & \\
\hline$\alpha_{1}$ & & \\
\hline$\beta_{1}$ & & \\
\hline Student-t & & \\
\hline Asymmetry & & \\
\hline Threshold & & \\
\hline Cond. Variance in Mean & & \\
\hline Constant Term & & \\
\hline $9 / 11$ & $-5.305^{*}$ & $-3.822 * *$ \\
\hline India/Pakistan/Russia & & $0.095 * *$ \\
\hline South Africa & & $0.051^{*}$ \\
\hline Wednesday & $0.118 * *$ & \\
\hline Thursday & $0.077 * *$ & $0.044 * *$ \\
\hline Friday & $0.132 * *$ & $0.061 * *$ \\
\hline Returns $_{\mathrm{t}-1}$ & $0.037 * *$ & $0.027 * *$ \\
\hline Returns ${ }_{t-2}$ & $-0.022 *$ & \\
\hline Returns $_{\mathrm{t}-5}$ & & $-0.014^{* *}$ \\
\hline S\&P $1200_{t-1}$ & $0.043 * *$ & $0.197 * *$ \\
\hline$S \& P 1200 \mathrm{t}-2$ & & $-0.016 *$ \\
\hline S\&P 1200 t-3 & & $0.035 * *$ \\
\hline S\&P $1200_{t-6}$ & $-0.028 * *$ & \\
\hline EMBIG $_{t-1}$ & $0.039 *$ & $0.063 * *$ \\
\hline $\mathrm{EMBIG}_{\mathrm{t}-2}$ & $0.036^{*}$ & \\
\hline $\mathrm{EMBIG}_{\mathrm{t}-3}$ & & $0.056 * *$ \\
\hline EMBIG $_{\mathrm{t}-6}$ & & $-0.036^{*}$ \\
\hline Broad U.S. FX $\mathrm{t}_{\mathrm{t}-2}$ & & $-0.083 * *$ \\
\hline
\end{tabular}

\begin{tabular}{|c|c|c|c|c|}
\hline & \multicolumn{2}{|c|}{ America } & \multicolumn{2}{|c|}{ Non-America } \\
\hline & Overall & Fin. Crisis & Overall & Fin. Crisis \\
\hline Target Rate Cut & & $2.050 * *$ & & \\
\hline Target Rate Cut Surprise & $0.761 * *$ & $-2.405^{* *}$ & $0.404 * *$ & \\
\hline Statement MP - & & $1.510^{* *}$ & & \\
\hline Statement EO + & & $0.533^{* *}$ & & \\
\hline Statement EO - & $-0.225^{*}$ & $-3.670 * *$ & & \\
\hline MPR EO - & & & $-0.244 * *$ & \\
\hline Testimony MP + & $-0.936 * *$ & & & \\
\hline Testimony MP - & & & & $0.889 *$ \\
\hline Testimony EO + & & & & $0.877 * *$ \\
\hline Speech MP + & $-0.301^{* *}$ & & & \\
\hline Speech MP - & & $0.375 *$ & & $0.366^{*}$ \\
\hline Speech EO + & $0.211 * *$ & & & $0.468 * *$ \\
\hline Speech EO - & & & & $-0.236^{*}$ \\
\hline Discount Rate Action & - & $3.466 * *$ & - & \\
\hline Joint Action w/ Government & - & $-1.943 * *$ & - & \\
\hline ABS Measure & - & $0.441^{*}$ & - & $0.628 * *$ \\
\hline
\end{tabular}

Notes: $*(* *)$ indicates significance at a 5\% (1\%) level. Standard errors are heteroscedasticity consistent. Number of observations: 50,881; 17 countries and 2,993 days. EO = Economic Outlook; MP = Monetary Policy. 
Table 1 shows that student-t errors with 3.1 degrees of freedom provide a better approximation to the residuals than a normal distribution. We find that last period's negative forecast errors have a larger impact on current volatility of the emerging equity markets than do positive errors, implying that unspecified negative news has more influence on volatility than does positive news. Furthermore, the conditional variance has a significantly negative impact on the mean equation. This suggests that investors move out of emerging stock markets during times of higher conditional volatility, as the required risk premium is not priced in emerging market returns. The performances of the Indian, Pakistani, Russian, and South African stock markets are better than average. Statistical testing shows $\left(\mathrm{Chi}^{2}(2)=\right.$ 0.909) that the first three of these markets can be combined into one dummy variable to enhance estimation efficiency. Day of the week effects are found for both regions; however they are stronger in the countries from the American region than in the non-American countries. $^{14}$

Weak market efficiency is violated as the first, second, and fifth lag can be used to predict today's outcome. ${ }^{15}$ Emerging equity markets are affected by global stock market conditions via lagged S\&P 1200 returns. An ascending EMBIG spread (i.e., the spread between emerging market bonds and a U.S. benchmark bond) increases stock market returns, which implies that investors move their capital into emerging equity markets in times of higher bond returns. Finally, an appreciation of the broad U.S. dollar index leads investors to move out of non-American emerging equity markets. ${ }^{16}$

Turning to monetary policy variables (bottom half of Table 1), we first describe the impact on emerging equity markets over the whole sample (the "Overall” columns). Target rate changes matter for both regions only in the case of a surprise cut: a 25 bps surprise cut increases American (non-American) market returns by 76 (40) bps. ${ }^{17}$ American markets are influenced by a greater variety of central bank communication and the reaction is also numerically larger. Statements referring to a negative economic outlook lower returns in

\footnotetext{
${ }^{14}$ A "Wednesday effect" is found only for the American countries and the "Friday effect" is statistically larger in American than in non-American countries $\left(\mathrm{Chi}^{2}(1)=8.9^{* *}\right)$. The "Thursday effect" is statistically equal in both regions $\left(\mathrm{Chi}^{2}(1)=1.8\right)$.

${ }^{15}$ For both regions markets, the sum of lagged returns is statistically insignificant $\left(\mathrm{Chi}^{2}(1)=1.1\right.$ for American countries; $\operatorname{Chi}^{2}(1)=2.3$ for non-American countries).

${ }^{16}$ In the case of changes in global equity conditions, non-American markets are more affected than American markets (test of significant differences between coefficients: $\mathrm{Chi}^{2}(1)=97.3^{* *}$ ). The impact of the bond market environment is statistically equal across both regions $\left(\mathrm{Chi}^{2}(1)=0.056\right)$.

Within American countries, the influence of equity and bond conditions is statistically equal $\left(\mathrm{Chi}^{2}(1)=3.8\right)$. In contrast, within non-American countries, the S\&P 1200 is more important than the EMBIG spread $\left(\mathrm{Chi}^{2}(1)=\right.$ $\left.15.6^{* *}\right)$ and the broad U.S. FX index $\left(\mathrm{Chi}^{2}(1)=21.3^{* *}\right)$. The influence of bond and FX conditions is statistically equal $\left(\mathrm{Chi}^{2}(1)=0.0002\right)$.

${ }^{17}$ Statistical testing reveals no evidence in favor of asymmetric adjustments between both regions $\left(\mathrm{Chi}^{2}(1)=\right.$ 2.1).
} 
American markets by 23 bps. Non-American markets are affected negatively when this type of news is disseminated in a monetary policy report (24 bps). Testimony hinting at a tightening of monetary policy depresses American markets by 94 bps-the biggest economic reaction across all target rate changes and communication variables for the entire period and statistically larger than the reaction to speeches with the same content (30 bps). ${ }^{18}$ Finally, a bright economic outlook results in a positive stock market reaction in American countries (21 bps). Considering the size of the reaction, one should take into account the median value of the absolute daily changes in emerging equity returns (74 bps) observed over the sample period, which implies that the impact of monetary policy actions and communications is of economic relevance.

The additional influence during the financial crisis is captured by interaction variables (the "Fin. Crisis" columns in the lower half of Table 1). Expected target rate cuts increase American equity returns by 205 bps. However, this coefficient is offset by the influence of surprise target rate cuts $(-241 \mathrm{bps}) .{ }^{19}$ If the central bank cuts the rate by more than expected (or at an unscheduled meeting), the action is interpreted by financial market agents as a signal that the central bank has new information, indicating that the economy will perform (much) worse than expected. This also explains why markets react drastically to a negative economic outlook disseminated in a post-meeting statement during the financial crisis (-360 bps). In general, central bank communication plays a more pronounced role in terms of significance and size of the coefficients during the financial crisis. Post-meeting statements are carefully monitored by American financial markets: a statement indicating future target rate cuts brings some relief to financial markets and drives returns up by 151 bps. The same holds for a bright economic outlook (53 bps). Finally, a speech conveying a future rate cut does raise returns by 38 bps, but is significantly less important than a post-meeting statement with the same content. ${ }^{20}$ Non-American markets are mostly influenced by speeches and testimony during the financial crisis. The indication of a future rate cut causes higher yields (89 bps for testimony, 37 bps for speeches), as does a brighter economic outlook (88 bps for testimony, 47 bps for speeches). ${ }^{21}$ In contrast, a negative economic outlook speech depresses returns in nonAmerican countries (24 bps).

The additional measures implemented by the Fed during the financial crisis affect American countries more than non-American countries. The discount rate cut on August 7,

\footnotetext{
${ }^{18} \mathrm{Chi}^{2}(1)=4.4^{*}$.

${ }^{19}$ The sum of both coefficients is statistically equal to zero $\left(\mathrm{Chi}^{2}(1)=0.502\right)$.

${ }^{20} \mathrm{Chi}^{2}(1)=13.6^{* *}$.

${ }^{21}$ There is no significant difference between testimony and speeches in either case $\left(\mathrm{Chi}^{2}(1)=1.8\right.$; $\left.\mathrm{Chi}^{2}(1)=1.7\right)$.
} 
2007 raises returns in the former countries by 347 bps. Measures to mitigate problems in the asset-backed security market lead to higher returns in both regions (44 bps in American countries, 63 bps in non-American countries).$^{22}$ Finally, coordinated actions by the Fed and federal government exert an influence similar to that of an unexpected target rate cut. Agents appear to believe that the coordinated effort is a signal that the situation is even worse than expected, causing returns to fall by 194 bps.

Next, we consider the economic impact of central bank communication in comparison with actual target rate changes by taking into account that the former occurs much more often than the latter.

Table 2: Cumulative Returns for American and Non-American Markets

\begin{tabular}{|c|c|c|c|c|}
\hline & \multicolumn{2}{|c|}{ America } & \multicolumn{2}{|c|}{ Non-America } \\
\hline & Overall & Fin. Crisis & Overall & Fin. Crisis \\
\hline Target Rate Cut & & 42.02 & & \\
\hline Target Rate Cut Surprise & 11.80 & -15.63 & 6.26 & \\
\hline Statement MP - & & 19.63 & & \\
\hline Statement EO + & & 4.80 & & \\
\hline Statement EO - & -6.06 & -36.70 & & \\
\hline MPR EO - & & & -1.95 & \\
\hline Testimony MP + & -3.74 & & & \\
\hline Testimony MP - & & & & 2.67 \\
\hline Testimony EO + & & & & 2.63 \\
\hline Speech MP + & -10.55 & & & \\
\hline Speech MP - & & 2.25 & & 2.20 \\
\hline Speech EO + & 20.86 & & & 3.74 \\
\hline Speech EO - & & & & -3.77 \\
\hline Discount Rate Action & - & 3.47 & - & \\
\hline Joint Action w/ Government & - & -11.66 & - & \\
\hline ABS Measure & - & 3.09 & - & 4.39 \\
\hline
\end{tabular}

Note: The variables are multiplied by their respective frequency per country to show their cumulative impact.

Table 2 shows the cumulative effects of communication events in our sample period, differentiated across markets and concentrating on the significant coefficients from Table 1. A relatively small number of interest rate cuts generate noteworthy effects on returns. In the American (non-American) countries, target rate cut surprises cause equity returns to rise by 11.8 (6.3) percentage points (pp) over the whole sample. However, the aggregated cumulative effects of informal communication are substantially larger than the impact of actual interest rate changes. This indicates that the coefficients estimated for single informal communication

\footnotetext{
${ }^{22}$ The influence is statistically equal across both regions $\left(\mathrm{Chi}^{2}(1)=0.401\right)$.
} 
events may disguise their actual importance for financial market movements. In particular, speeches conveying a bright economic outlook cause the largest cumulative reaction of all variables. American market returns are raised by 20.9 pp-an impact nearly twice as large as that caused by target rate cut surprises. Furthermore, Table 2 confirms that over the full sample, American markets are more affected than non-American markets: U.S. communication causes an absolute adjustment of American markets by $41.2 \mathrm{pp}$, whereas the impact on non-American markets is $2 \mathrm{pp}$.

The influence of U.S. monetary policy action and communication during the financial crisis is noteworthy. Target rate cuts move American countries an additional 26.4 pp during that period-even after correcting for the offsetting effects of target rate cut surprises. Statements and additional measures by the Fed are the most important categories for American markets, confirming the impression from Table 1. For instance, the cumulative impact of post-meeting statements conveying a negative economic outlook is $-36.7 \mathrm{pp}$ and joint actions of the Fed and federal government move markets by a total of $-11.7 \mathrm{pp}$. For nonAmerican markets, the cumulative absolute impact of testimony and speeches is "only" about 15 pp. Thus, as is the case in "normal” times, during the financial crisis, American countries are relatively more influenced by U.S. monetary policy actions and communications than are non-American countries.

For both the full sample period and during the financial crisis, American markets react more to U.S. monetary policy actions and communications than do non-American countries. In explaining regional differences in a related context, Ehrmann and Fratzscher (2009) and Wongswan (2009) emphasize the importance of global integration and financial integration with the United States, respectively. Our work lends support to these explanations, as the trade share of American countries with the United States is between $37-57 \%$ (see Table A2 in the Appendix), whereas non-American countries have trade shares of only between $11-17 \%$. Moreover, the financial integration of American countries, measured by the share of portfolio investment from the United States, is between 47-54\% (see Table A3 in the Appendix); the share of portfolio investment in non-American countries ranges from 33 to $45 \%$.

In our view, the differences between American and non-American markets may have yet another cause. In a different context, Boubaker and Sebai (2009) find stronger intracontinent causalities in stock markets than between stock markets in different continents. They explain this finding by the fact that in the former case, any significant correlation is realized on the same calendar day, while there is a time lag between continents. Cai et al. (2008) study informational linkages in the euro-dollar and dollar-yen exchange rates across 
five trading regions. They find that informational linkages within regions are more important than those across regions. Figure 1 shows that news hits the American markets (mostly) nearly simultaneously with its occurrence, whereas there is a time lag (mostly overnight) before the non-American markets receive the same news. Our results suggest that the impact of news dissipates overnight as non-American markets do not react to the same extent as American markets. Thus, we argue that the larger reaction of American markets can be explained by overlapping trading hours between them and the United States, resulting in U.S. news arriving in these markets while they are still open, in addition to their greater degree of economic and financial integration with the United States.

\section{Conclusions and Policy Implications}

In this paper, we study the effects of U.S. monetary policy action and communication on emerging equity market returns. Using a GARCH model, we analyze the influence of target rate changes, post-meeting statements, monetary policy reports, testimony, and speeches over the period 1998-2009, thus covering the recent financial crisis. We concentrate our analysis on four research questions.

First, does U.S. monetary policy action and communication have an economically significant impact on equity returns in emerging markets? We show that target rate change surprises and central bank communication have a significant impact on emerging equity market returns. Ranging from 21 to 94 basis points over the whole sample, the magnitude of these effects is of economic relevance given the median value of the absolute daily changes in emerging equity returns (74 bps) in our sample.

Second, if so, do markets react differently to official rate changes versus less formalized channels of monetary policy like speeches and testimony? Our point estimates suggest that the reactions are in a comparable range. However, informal communicationparticularly when taking into account its higher frequency-exerts a larger (cumulative) influence on returns. Specifically, speeches conveying a bright economic outlook result in the largest cumulative reaction of all variables. American market returns are raised by $20.9 \mathrm{pp}-$ nearly twice the size of the impact caused by target rate cut surprises.

Third, is there a different reaction to U.S. monetary policy measures during the financial crisis, which began in August 2007? In general, central bank communication plays a more pronounced role in terms of significance and size of the coefficients during the financial crisis. For example, the additional cumulative influence of negative post-meeting statements in American markets is -36.7 pp. Target rate changes also exert a larger influence in the crisis 
period than during "normal times." Several additional measures implemented by the Fed to mitigate the problems in the financial sector also cause a significant movement in emerging market returns.

Finally, are there region-specific differences in emerging market reactions? We find significant variation in the reactions of American and non-American emerging markets-over the full sample and during the financial crisis - which we explain by differences in when the news reaches the markets. Occurrence and dissemination of news are nearly simultaneous for the American markets, whereas non-American markets experience a time lag (mostly overnight) before news can affect financial market prices. In addition, American emerging economies are more closely integrated with the United States in real and financial terms than are non-American emerging markets and, therefore, Fed monetary policy news has a larger impact on this group of countries.

Our results have important implications for policymakers and investors. First, in addition to observing formal announcements, investors and policymakers need to pay attention to informal communication of U.S. monetary policy. Hayo et al. (2010) present similar findings for mature European and Pacific equity markets, although their results suggest that mature equity markets are even more influenced by communication and to a lesser extent by monetary policy actions. Arguably, these well-developed markets have a more sophisticated understanding of monetary policy than do emerging equity markets and thus are more alert to the possibly subtler nuances of informal communication. Based on these results, we conjecture that as these emerging markets continue to evolve, informal communication will become increasingly important to them. The increased influence of central bank communication during the financial crisis seems to support this conjecture.

Second, the strong reactions during the financial crisis show how crucial central bank communication is in turbulent times. Financial markets closely monitor every speech and adjust their prices in reaction to a larger extent than they do during "normal times.”

Third, the finding that American stock markets react more strongly to news of policy shocks from the United States than do non-American stock markets suggests that the former countries have a higher risk of contagion via both formal and informal channels and that investors focusing on the American region face a lower degree of portfolio diversification opportunities.

Finally, in an extension of the analysis presented above, we find that U.S. monetary policy news has a larger impact on returns than on the volatility of returns. This suggests that the Fed's actions generate primarily wealth effects rather than risk effects, as measured by the 
conditional variance of returns. $^{23}$ Thus, U.S. monetary policy announcements can significantly impact the wealth of investors in emerging economies, especially in the neighboring American economies. Prudent policymakers in these emerging markets should design policy strategies that effectively deal with the wealth and other effects of U.S. monetary policy actions and communications.

\footnotetext{
${ }^{23}$ We insert our variables of interest in the volatility part of Equation (1). However, the size of the very few significant coefficients indicates an almost negligible economic impact. Results are available on request.
} 


\section{References}

Alper, C. E. (2006), U.S. Monetary Policy Surprises and Emerging Markets Sovereign Spreads, 2007 AEA Conference Papers.

Andersson, M., Dillén, H., and Sellin, P. (2006), Monetary Policy Signalling and Movements in the Term Structure of Interest Rates, Journal of Monetary Economics 53 (8), 18151855.

Andritzky, J. R., Bannister, G. J., and Tamirisa, N. T. (2007), The Impact of Macroeconomic Announcements on Emerging Market Bonds, Emerging Markets Review 8 (1), 20-37.

Arora, V. and Cerisola, M. (2001), How Does U.S. Monetary Policy Influence Sovereign Spreads in Emerging Markets? IMF Staff Papers 48 (3).

Blinder, A., Ehrmann, M., Fratzscher, M., de Haan, J., and Jansen, D.-J. (2008), Central Bank Communication and Monetary Policy: A Survey of Theory and Evidence, Journal of Economic Literature 46 (4), 910-945.

Bollerslev, T. (1986), Generalized Autoregressive Conditional Heteroscedasticity, Journal of Econometrics 31 (3), 307-327.

Bollerslev, T. (1987), A Conditional Heteroscedastic Model for Speculative Prices and Rates of Return, Review of Economics and Statistics 69 (3), 542-547.

Boubaker, A. and Sebai, S. (2009), Inter-Market Information Flow: A Nonlinear Approach, Applied Economics Letters, 16 (10), 1009-1015.

Büttner, D., Hayo, B., and Neuenkirch, M. (2009), The Impact of Foreign News on Financial Markets in the Czech Republic, Hungary, and Poland, MAGKS Joint Discussion Paper Series in Economics 03-2009.

Cai, F., Howorka, E., and Wongswan, J. (2008), Informational Linkages Across Trading Regions: Evidence from Foreign Exchange Markets, Journal of International Money and Finance 27 (8), 1215-1243.

Connolly, E. and Kohler, M. (2004), News and Interest Rate Expectations: A Study of Six Central Banks, in: Kent, C. and Guttmann, S., The Future of Inflation Targeting, Reserve Bank of Australia, 108-134.

Dailami, M., Masson, P. R., and Padou, J. J. (2008), Global Monetary Conditions Versus Country-Specific Factors in the Determination of Emerging Market Debt Spreads, Journal of International Money and Finance 27 (8), 1325-1336

Dickey, D. A. and Fuller, W. A. (1979), Distribution for Autoregressive Time Series with a Unit Root, Journal of the American Statistical Association 74 (366), 427-431.

Ehrmann, M. and Fratzscher, M. (2007), Communication by Central Bank Committee Members: Different Strategies, Same Effectiveness? Journal of Money, Credit and Banking 39 (2-3), 509-541.

Ehrmann, M. and Fratzscher, M. (2009), Global Financial Transmission of Monetary Policy Shocks, Oxford Bulletin of Economics and Statistics 71 (6), 739-759.

Engle, R. F. (1982), Autoregressive Conditional Heteroscedasticity with Estimates of the Variance of United Kingdom Inflation, Econometrica 50 (4), 987-1008.

Engle, R. F., Lilien, D. M., and Robbins, R. P. (1987), Estimating Time-Varying Risk Premia in the Term Structure: The ARCH-M Model, Econometrica 55 (2), 391-407.

Engle, R. F. and Ng, V. K. (1993), Measuring and Testing the Impact of News on Volatility, Journal of Finance 48 (5), 1749-1778. 
Fender, I., Hayo, B., and Neuenkirch, M. (2010), Monetary Policy Spillovers and Emerging Market Credit: The Impact of Federal Reserve Communications on Sovereign CDS Spreads, mimeo.

Glosten, L. R., Jagannathan, R., and Runkle, D. E. (1993), On the Relation Between the Expected Value and the Volatility of the Nominal Excess Return on Stocks, Journal of Finance 48 (5), 1779-1801.

Guthrie, G. and Wright, J. (2000), Open Mouth Operations, Journal of Monetary Economics 46 (2), 489-516.

Hausman, J. and Wongswan, J. (2006), Global Asset Prices and FOMC Announcements, Board of Governors of the Federal Reserve System International Finance Discussion Papers Number 886.

Hayo, B. and Kutan, A. M. (2005), IMF-Related News and Emerging Financial Markets, Journal of International Money and Finance 24 (7), 1126-1142.

Hayo, B., Kutan, A., and Neuenkirch, M. (2008), Communicating with Many Tongues: FOMC Communication, Media Coverage, and U.S. Financial Market Reaction, MAGKS Joint Discussion Paper Series in Economics 08-2008.

Hayo, B., Kutan, A., and Neuenkirch, M. (2010), The Impact of U.S. Central Bank Communication on European and Pacific Equity Markets, Economics Letters 108 (2), 172174.

Hayo, B. and Neuenkirch, M. (2010), Domestic or U.S. News: What Drives Canadian Financial Markets? Economic Inquiry forthcoming.

Hendry, D. F. (2000), Econometrics: Alchemy or Science? Essays in Econometric Methodology, New Edition, Oxford: Oxford University Press.

International Monetary Fund (2002), Coordinated Portfolio Investment Survey Guide, Second Edition.

Miniane, J. and Rogers, J. H. (2007), Capital Controls and the International Transmission of U.S. Money Shocks, Journal of Money, Credit and Banking 39 (5), 1003-1035.

Nelson, D. (1990), Stationarity and Persistence in the GARCH(1,1) Model, Econometric Theory 59 (2), 318-334.

Özatay, F., Özmen, E., and Sahinbeyoglu, G. (2009) Emerging Market Sovereign Spreads, Global Financial Conditions and U.S. Macroeconomic News, Economic Modelling 26 (2), 526-531.

Ranaldo, A. and Rossi, E. (2010), The Reaction of Asset Markets to Swiss National Bank Communication, Journal of International Money and Finance 29, 486-503.

Reinhart, C. M. and Rogoff, K. S. (2004), The Modern History of Exchange Rate Arrangements: A Reinterpretation, Quarterly Journal of Economics 119 (1), 1-48.

Robitaille, P. and Roush, J. (2006), How Do FOMC Actions and U.S. Macroeconomic Data Announcements Move Brazilian Sovereign Yield Spreads and Stock Prices? Board of Governors of the Federal Reserve System, International Finance Discussion Papers, Number 868, September 2006.

Uribe, M. and Yue, V. Z. (2006), Country Spreads and Emerging Countries: Who Drives Whom? Journal of International Economics 69 (1) 6- 36

Wongswan, J. (2009), The Response of Global Equity Indexes to U.S. Monetary Policy Announcements, Journal of International Money and Finance 28 (2) 344-365. 


\section{Appendix}

\section{Examples of Speeches and Their Coding}

Remarks by Chairman Alan Greenspan before the Economic Club of New York (May 24, $\underline{2001)}$

Moreover, with inflation low and likely to be contained, the main threat to satisfactory economic performance appeared to come from excessive weakness in activity. So we took out the restraint inherent in our previous policy stance and have moved policy to a more accommodative posture to counter the effects of the downshift in demand. ... The period of sub-par economic growth is not yet over, and we are not free of the risk that economic weakness will be greater than currently anticipated, requiring further policy response.

\section{Coding:}

Speech Economic Outlook Negative (EO-)

Speech Monetary Policy Easing (MP-)

Testimony of Chairman Alan Greenspan before the Joint Economic Committee, U.S. Senate (April 21, 2004)

The economy appears to have emerged around the middle of last year from an extended stretch of subpar growth and entered a period of more vigorous expansion. After having risen at an annual rate of $21 / 2$ percent in the first half of last year, real GDP increased at an annual pace of more than 6 percent in the second half. ... Although real GDP is not likely to continue advancing at the same pace as in the second half of 2003, recent data indicate that growth of activity has remained robust thus far this year. ... As I have noted previously, the federal funds rate must rise at some point to prevent pressures on price inflation from eventually emerging.

\section{Coding:}

Testimony Economic Outlook Positive (EO+)

Testimony Monetary Policy (MP+) 
Table A1: Descriptive Statistics of Equity Market Returns

\begin{tabular}{lcccccc}
\hline \hline & Mean & Std. Dev. & Skewness & Exc. Kurtosis & Minimum & Maximum \\
\hline Overall & 0.065 & 1.75 & 0.294 & 13.75 & -21.86 & 33.40 \\
\hline Argentina & 0.073 & 2.29 & 0.065 & 4.89 & -13.32 & 17.49 \\
Brazil & 0.093 & 2.31 & 1.134 & 19.75 & -15.83 & 33.40 \\
Chile & 0.047 & 0.82 & 0.802 & 21.33 & -4.89 & 12.42 \\
China & 0.047 & 1.69 & -0.002 & 5.14 & -11.98 & 9.86 \\
Egypt & 0.073 & 1.74 & -0.088 & 6.31 & -16.00 & 14.55 \\
India & 0.071 & 1.79 & -0.122 & 7.77 & -14.13 & 17.74 \\
Indonesia & 0.082 & 1.76 & 0.175 & 6.74 & -12.13 & 14.03 \\
Israel & 0.056 & 1.36 & -0.177 & 4.41 & -8.08 & 10.28 \\
Jordan & 0.048 & 1.29 & 0.444 & 47.64 & -18.57 & 21.99 \\
Malaysia & 0.042 & 1.38 & 2.167 & 41.78 & -13.28 & 23.14 \\
Mexico & 0.078 & 1.65 & 0.383 & 5.07 & -9.82 & 12.92 \\
Pakistan & 0.077 & 1.77 & -0.126 & 5.12 & -12.38 & 13.61 \\
Peru & 0.082 & 1.48 & 0.531 & 17.60 & -10.81 & 19.88 \\
Philippines & 0.035 & 1.58 & 0.827 & 13.43 & -12.27 & 17.56 \\
Russia & 0.090 & 2.80 & -0.108 & 7.80 & -21.86 & 22.39 \\
South Africa & 0.067 & 1.39 & -0.119 & 3.40 & -7.59 & 7.39 \\
Thailand & 0.041 & 1.74 & 0.282 & 7.57 & -14.84 & 12.02 \\
\hline \hline
\end{tabular}

Table A2: Trade with the United States

\begin{tabular}{lcccccccccccc}
\hline \hline & $\mathbf{1 9 9 8}$ & $\mathbf{1 9 9 9}$ & $\mathbf{2 0 0 0}$ & $\mathbf{2 0 0 1}$ & $\mathbf{2 0 0 2}$ & $\mathbf{2 0 0 3}$ & $\mathbf{2 0 0 4}$ & $\mathbf{2 0 0 5}$ & $\mathbf{2 0 0 6}$ & $\mathbf{2 0 0 7}$ & $\mathbf{2 0 0 8}$ & $\mathbf{2 0 0 9}$ \\
\hline American & 250 & 278 & 334 & 311 & 301 & 304 & 342 & 378 & 428 & 457 & 498 & 378 \\
\% American & $52 \%$ & $57 \%$ & $57 \%$ & $55 \%$ & $55 \%$ & $52 \%$ & $48 \%$ & $46 \%$ & $43 \%$ & $40 \%$ & $37 \%$ & $37 \%$ \\
\hline Non-Am. & 174 & 184 & 215 & 209 & 229 & 262 & 327 & 389 & 463 & 517 & 570 & 483 \\
\% Non-Am. & $17 \%$ & $17 \%$ & $16 \%$ & $16 \%$ & $15 \%$ & $14 \%$ & $13 \%$ & $13 \%$ & $13 \%$ & $12 \%$ & $11 \%$ & $11 \%$ \\
\hline \hline
\end{tabular}

Trade with the United States in billions of USD and as a percentage of total trade.

Source: IMF Direction of Trade Statistics.

Table A3: Portfolio Investment from the United States

\begin{tabular}{lcccccccc}
\hline \hline & $\mathbf{2 0 0 1}$ & $\mathbf{2 0 0 2}$ & $\mathbf{2 0 0 3}$ & $\mathbf{2 0 0 4}$ & $\mathbf{2 0 0 5}$ & $\mathbf{2 0 0 6}$ & $\mathbf{2 0 0 7}$ & $\mathbf{2 0 0 8}$ \\
\hline American & 94 & 83 & 120 & 146 & 195 & 242 & 321 & 171 \\
\% American & $47 \%$ & $51 \%$ & $50 \%$ & $51 \%$ & $54 \%$ & $52 \%$ & $53 \%$ & $50 \%$ \\
\hline Non-American & 60 & 73 & 113 & 136 & 183 & 243 & 362 & 178 \\
\% Non-American & $42 \%$ & $45 \%$ & $41 \%$ & $38 \%$ & $37 \%$ & $36 \%$ & $35 \%$ & $33 \%$ \\
\hline \hline
\end{tabular}

Portfolio investment from the United States in billions of USD and as a percentage of total investment. Data are not available for China, Jordan, or Peru.

Source: Coordinated Portfolio Investment Survey (IMF, 2002). 